\title{
Summertime wave height variability along the Pacific and Okhotsk Sea coasts of northern Japan
}

\author{
Teruhisa Shimada*
}

Graduate School of Science, Tohoku University, Aramaki Aza Aoba 6-3, Aoba-ku, Sendai, Miyagi 980-8578, Japan

\begin{abstract}
Wave height variability along the Pacific and Okhotsk Sea coasts of northern Japan in June-August is investigated using in situ measurements and reanalysis data. The coastal wave height is dominated by the persistent easterly winds induced by the developed Okhotsk high. These winds, which can induce cool summers in northern Japan, favor wave development toward the coast of northern Japan. The wave variability is enhanced along the coast of northern Tohoku by the strong local winds occurring in the lee of Cape Erimo. The results for variability of wave height along the Pacific and Okhotsk Sea coasts of northern Japan are supported by composite analysis of reanalysis wave data. When the Okhotsk high develops and the resulting easterly winds are dominant, the wave height increases near the coast of and to the east of northern Japan. Wave height also increases in the Japan Sea and along the southern coast of Japan, whereas wave height decreases in the Okhotsk Sea. These wave height variations reflect the distinct wind fields associated with the developed Okhotsk high. Trends in wave height are examined using the in situ measurements available for over 20 yr. Only the decreasing trends in the south of northern Japan in August are statistically significant.
\end{abstract}

KEY WORDS: Wave climate - Okhotsk high - Northern Japan - Significant wave height · Cool summer $\cdot$ Yamase

\section{INTRODUCTION}

The relationships between large-scale atmospheric patterns and regional ocean wave climate are key elements for understanding the present wave climate and for assessing future changes in wave climate (e.g. WASA group 1998). The relation between the North Atlantic Oscillation and wave height variability in the North Atlantic and the Mediterranean Sea is under active investigation (e.g. WASA group 1998, Woolf et al. 2002, Lionello \& Sanna 2005, Charles et al. 2012, Fan et al. 2012). In the North Pacific, the Pacific-North America pattern and the West Pacific pattern affect the wave climate in winter (e.g. Wang \& Swail 2001, Shimura et al. 2013). Relations between other atmospheric patterns and wave climate have also been discussed (Fan et al. 2012, Shimura et al. 2013, Stopa et al. 2013). These relations provide the basis for evaluating projections of future changes in wave climate (e.g. Caires et al. 2006, Wang \& Swail 2006, Mori et al. 2010, Hemer et al. 2013).

In the western North Pacific and the Okhotsk Sea, summertime wave climate is generally influenced by the prevailing East Asian monsoon (e.g. Young 1999; Fig. 1), and southerly winds and northward waves dominate. However, a high-pressure system over the Okhotsk Sea (the Okhotsk high) develops intermittently and induces cool easterly winds blowing toward northern Japan (Figs. 1 \& 2) during the summer months (June to August) (e.g. Ninomiya \& Mizuno 1985, Shimada et al. 2014). This cool easterly wind, known as the Yamase in Japan, can persist for more than several days with a stagnant Okhotsk high. Meanwhile, the strength and persistence of the easterly winds show large interannual variation in accordance with the activity of the Okhotsk high (e.g. 


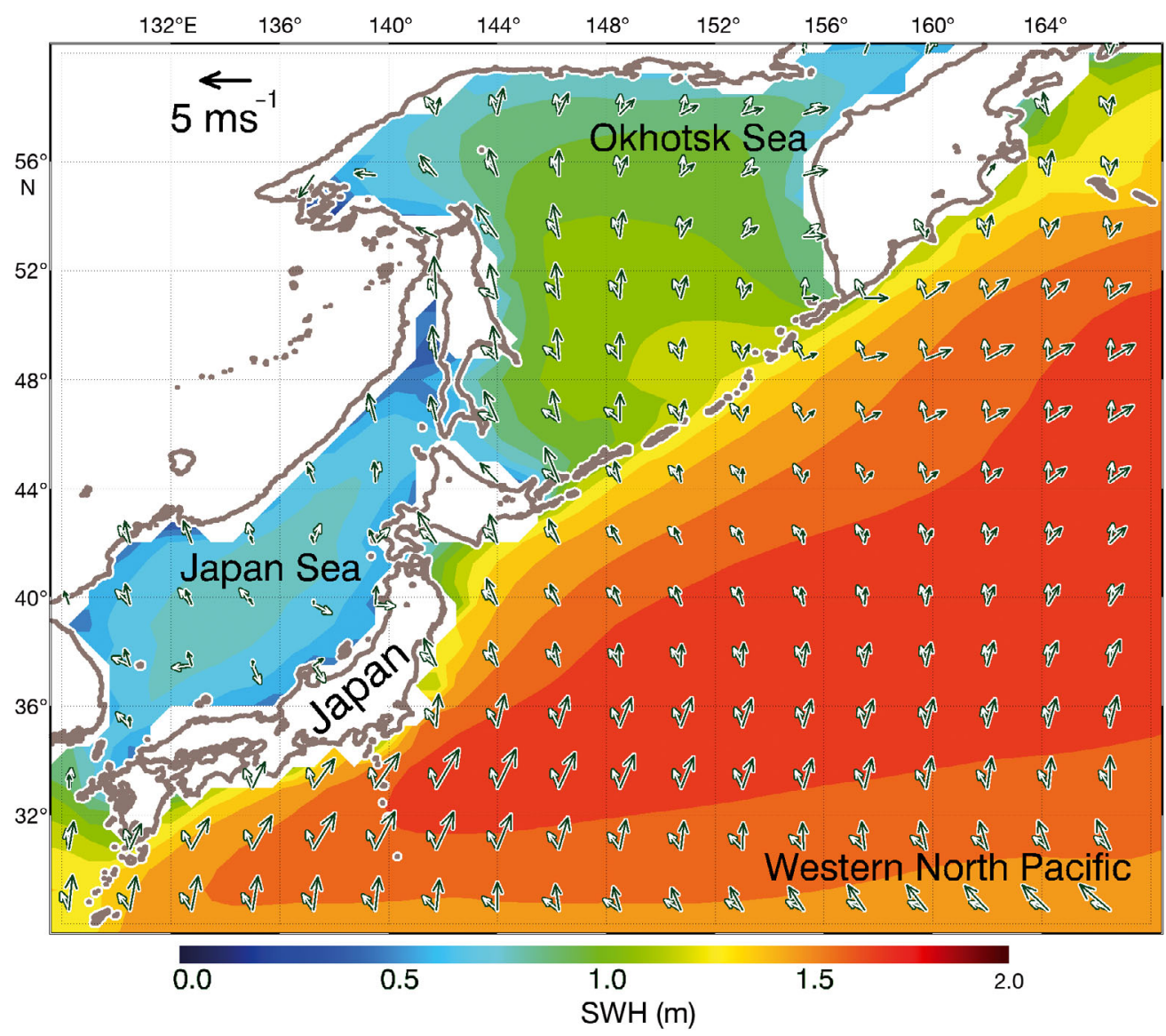

Fig. 1. Climatology of significant wave height ( $\mathrm{SWH}_{\text {; }}$ color shading), mean wave direction (white vectors with a fixed length), and $10 \mathrm{~m}$ winds (black vectors) in June-August for 1979 to 2010 from the ERA-Interim data

Tachibana et al. 2004), and such persistent easterly winds have caused record cool summers (e.g. Ninomiya \& Mizuno 1985). The persistent easterly winds induced by the developed Okhotsk high create conditions of large fetch and extended duration, favoring the development of waves toward the eastern coast of northern Japan, and thus the variability of the easterly winds should affect summertime wave variability along the Pacific and Okhotsk Sea coasts of northern Japan. In addition, strong local winds frequently develop owing to the effects of coastal topography on the low-level cool airflow induced by the developed Okhotsk high and influence wave development near the coast of northern Japan (Shimada \& Kawamura 2007). The strong local winds underlie the regional differences in wave variability.

Little attention has been given to the impact of the easterly winds induced by the Okhotsk high on wave variability along the Pacific and Okhotsk Sea coasts of northern Japan. This is probably because average wave heights are at a minimum in summer along these coasts (Fig. 3). The seasonal variation of signif- icant wave height (SWH) in Fig. 3 is representative of conditions in the region. Bimodal peaks of SWH reflect the frequent development of extratropical cyclones off the Pacific coast of northern Japan in spring (March to April) and fall (September to October) and the passage of tropical cyclones over the western North Pacific in fall. In winter (November to February), mean SWHs ( 1.2 m) are not as high as in spring and fall, because the fetch is reduced by the prevailing northwesterly East Asian winter monsoon. At the same time, the 90th percentile SWH in winter is high, up to $2.4 \mathrm{~m}$, due to the passage of extratropical cyclones with subsequent outbreaks of the winter monsoon. Wave variability in spring, fall, and winter has been analyzed (e.g. Arakawa \& Suda 1953, Shimada \& Kawamura 2004), but few studies have documented summertime wave variability attributable to the interannual variability of the Okhotsk high and to the strong local winds near the coast. Therefore, this study investigates summertime wave variability along the Pacific and Okhotsk Sea coasts of northern Japan to show (1) the relation of this wave variability 


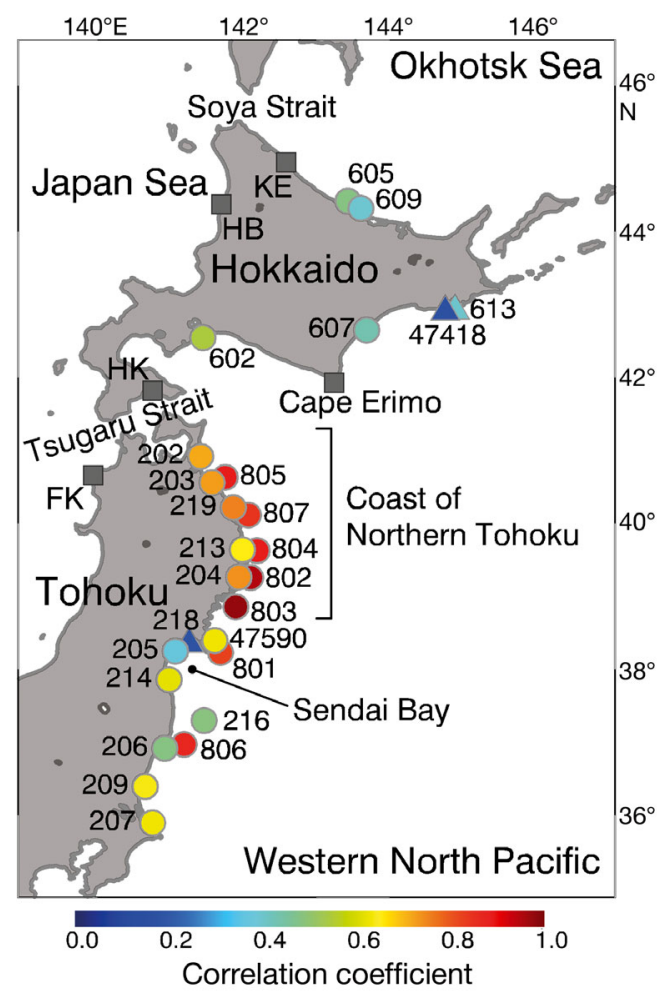

Fig. 2. Weather observation stations (gray squares: Hakodate, HK; Fukaura, FK; Kitamiesashi, KE; Haboro, HB; Cape Erimo) and wave observation sites (colored symbols). The colors indicate correlation coefficients between monthly means of SWH at the wave observation sites and of the Yamase indices. Circles: statistically significant correlations with $\mathrm{p}=0.95$; triangles: not significant

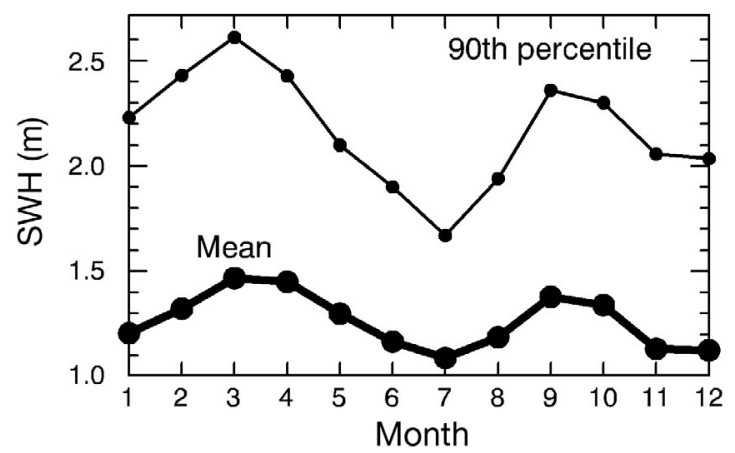

Fig. 3. Monthly means and 90th percentiles of significant wave height (SWH) at observation site 47590 for 1978-2010

to the atmospheric field associated with cool summers and (2) its regional differences, using in situ measurements of wave and wave reanalysis data.

The data and methods are described in the following section. Section 3 presents the variability in $\mathrm{SWH}$ and Section 4 discusses the results. Section 5 contains the conclusions.

\section{DATA AND METHODS}

This study used in situ measurements of ocean surface waves at 26 observation sites along the Pacific and Okhotsk Sea coasts of northern Japan in June-August (Fig. 2, Table 1). The Japan Meteorological Agency (JMA) operated ultrasonic wave gauges at observation sites 47590 and 47418 to conduct hourly wave measurements. For the measurements at observation site 47590, the 3-hourly data acquired before 14 March 1992 were linearly interpolated into hourly data. The other 24 observation sites belong to the Japanese coastal wave observation and analysis system, the Nationwide Ocean Wave Information Network for Ports and Harbours (NOWPHAS), which has been in operation since the

Table 1. Wave observation sites (see Fig. 2). The water depths cited are from the latest information during the analyzed period. Trends in 90th percentile significant wave height (SWH) in August are shown only for the observation sites with over $20 \mathrm{yr}$ of data, and the asterisk indicates a statistically insignificant trend with $\mathrm{p}=0.95$

\begin{tabular}{|c|c|c|c|c|}
\hline Region & $\begin{array}{c}\text { Site } \\
\text { identifier }\end{array}$ & $\begin{array}{l}\text { Water depth } \\
\qquad(\mathrm{m})\end{array}$ & $\begin{array}{c}\text { No. of } \\
\text { monthly data }\end{array}$ & $\begin{array}{c}\text { Trend } \\
\left(\mathrm{cm} \mathrm{yr}^{-1}\right)\end{array}$ \\
\hline \multicolumn{5}{|c|}{ Okhotsk Sea } \\
\hline & 605 & 52.0 & 52 & - \\
\hline & 609 & 52.6 & 30 & - \\
\hline \multicolumn{5}{|c|}{ South coast of Hokkaido } \\
\hline & 613 & 50.1 & 18 & - \\
\hline & 47418 & 47 & 47 & - \\
\hline & 607 & 23.0 & 42 & - \\
\hline & 602 & 50.7 & 120 & $-0.1^{*}$ \\
\hline \multicolumn{5}{|c|}{ East coast of northern Japan } \\
\hline & 202 & 43.8 & 109 & $-0.4^{*}$ \\
\hline & 805 & 87 & 6 & - \\
\hline & 203 & 27.7 & 107 & $0.0^{*}$ \\
\hline & 219 & 49.5 & 43 & - \\
\hline & 807 & 125 & 6 & - \\
\hline & 213 & 24.2 & 53 & - \\
\hline & 804 & 200 & 6 & - \\
\hline & 204 & 49.8 & 86 & \\
\hline & 802 & 204 & 6 & - \\
\hline & 803 & 160 & 4 & - \\
\hline & 47590 & 57 & 98 & -1.6 \\
\hline & 801 & 144 & 6 & - \\
\hline & 218 & 20.8 & 38 & - \\
\hline & 205 & 21.3 & 79 & -1.3 \\
\hline & 214 & 17.1 & 80 & -1.9 \\
\hline & 216 & 154.5 & 26 & - \\
\hline & 806 & 137 & 6 & - \\
\hline & 206 & 23.8 & 81 & -2.4 \\
\hline & 209 & 30.3 & 86 & $-1.3^{*}$ \\
\hline & 207 & 24.0 & 88 & $-0.7^{*}$ \\
\hline
\end{tabular}


1970s. The NOWPHAS data were obtained from the Ports and Harbor Bureau of the Ministry of Land, Infrastructure, Transport and Tourism, Japan. Twohourly wave measurements were obtained from 17 ultrasonic-based (pressure- and electrode-type in the early years) wave gauges at the near-coast locations with site identifiers in the 600s and 200s and from 7 Global Positioning System buoys moored 10 to $20 \mathrm{~km}$ from the coast with site identifiers in the 800s. For both wave datasets, the available data periods differ with observation site because of different observation start and end dates and different data gaps. This study used all available data ranging from the beginning of observations at each individual observation site up to 2010; the majority of the observation systems along the Pacific coast of Tohoku ceased operation due to the Tohoku-Oki earthquake and tsunami on 11 March 2011. Monthly values were defined for the present analysis when the observation coverage exceeded $80 \%$ during a month. The numbers of available monthly values in June-August at the individual observation sites are summarized in Table 1.

Surface-pressure data at 4 weather observation stations operated by the JMA (Fig. 2) were used to define the climate indices described below. Surface wind data at the JMA station located at Cape Erimo at an elevation of $63 \mathrm{~m}$ (Fig. 2) were also used. SWH and mean wave direction in June-August for 1979-2010 were obtained from 6-hourly products of the European Centre for Medium-Range Weather Forecasts (ECMWF) Re-Analysis Interim (ERAInterim; Dee et al. 2011).

To represent the variability of the atmospheric pattern associated with the developed Okhotsk high and of the resulting persistent easterly winds (or the Yamase), this study used 2 Yamase indices (the Tsugaru Strait index and the Soya Strait index; Shimada et al. 2014).

(1) The Tsugaru Strait index is defined by the sealevel pressure (SLP) difference between weather observation stations Hakodate and Fukaura along the Tsugaru Strait (Fig. 2). Although this index is locally defined, it represents the atmospheric field that induces the cool summer conditions in northern Japan. For example, high positive monthly means of this index correspond to periods when northern Japan experienced record cool summers (Fig. 4; August 1980, July 1988, July 1993, and July 2003). In particular, positive values of this index represent southward advance of cool air and enhanced easterly winds blowing toward the entire Pacific coast of northern Japan (Fig. 9c in Shimada et al. 2014). Thus, the Tsugaru Strait index is suitable for examining the wind variability near the Pacific coast of and to the east of northern Japan.
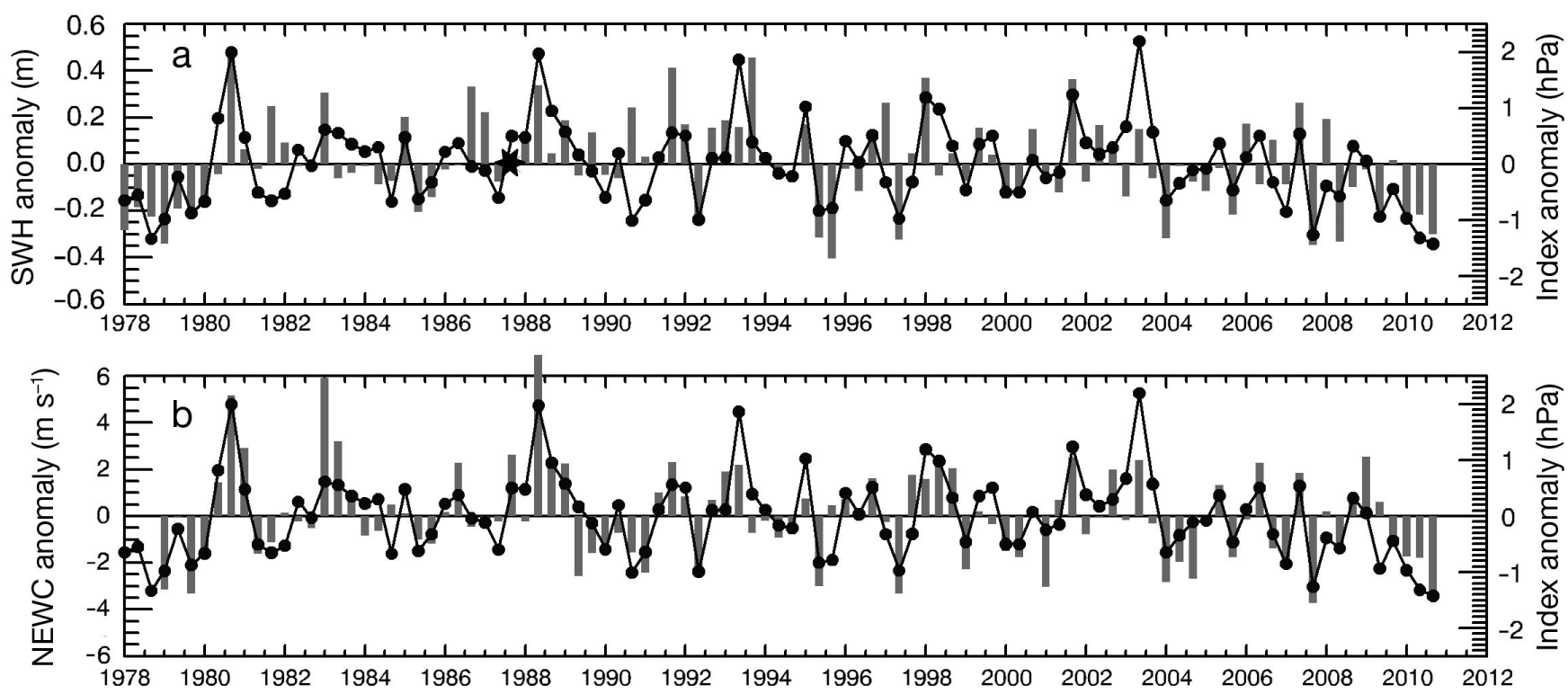

Fig. 4. (a) Monthly anomalies of significant wave height (SWH) at observation site 47590 (bars) and of the Tsugaru Strait index (solid line) in June-August for 1978-2010. The anomalies for SWH and the Tsugaru Strait index are defined with respect to the mean values during the period of $1.15 \mathrm{~m}$ and $0.75 \mathrm{hPa}$, respectively. The asterisk in August 1987 for SWH indicates that the monthly mean is not defined because of a long data gap. (b) The same as (a) but for the monthly anomalies of the northeasterly wind component (NEWC) at Cape Erimo (bars) in June-August for 1979-2010. The mean value for the northeasterly wind component during the period is $2.39 \mathrm{~m} \mathrm{~s}^{-1}$ 
(2) The Soya Strait index is an analogous index defined by the SLP difference between stations Kitamiesashi and Haboro along the Soya Strait (Fig. 2). This index represents a more northern center of cool air than the Tsugaru Strait index and enhanced northeasterly winds in the southern Okhotsk Sea (Fig. 9d in Shimada et al. 2014). Thus, the Soya Strait index is suitable for representing the wind variability in the Okhotsk Sea.

\section{RESULTS}

The relation between the monthly variability of the SWH and the Tsugaru Strait index is examined using the $33 \mathrm{yr}$ time series of SWH at observation site 47590 (Fig. 4a). The monthly anomalies are well correlated, with an overall correlation coefficient of 0.63 in JuneAugust, and correlation coefficients for June, July, and August are 0.63, 0.78, and 0.65, respectively. Thus, the variability of the Okhotsk high and the resulting easterly winds significantly affect the coastal wave height at the observation site. We can also see from Fig. 4a that the monthly variability, as well as the variability on an interannual basis, is significant. Incidentally, no significant correlation is found between monthly means of significant wave period and the Tsugaru Strait index, whereas Charles et al. (2012) showed a significant correlation between the significant wave period on the Atlantic coast and the climate indices for the Atlantic Ocean. The variability of the wave period merits further study, possibly from the perspective of the effect of swell from the south.

Do the SWH variations in other areas exhibit the same relation to the Yamase index, as shown in Fig. 4a? Fig. 2 shows correlation coefficients between monthly means of the Yamase index and of SWH at the observation sites. The Tsugaru Strait index is used for the Pacific coast and the Soya Strait index is used for the Okhotsk Sea coast. The significance of the correlations depends partly on the number of data at each observation site, and the mean SWH at each observation site varies with location because of the surrounding topography and water depth at which the instruments are installed. However, we should take notice of both the significant correlations along almost the entire Pacific and Okhotsk Sea coasts of northern Japan and the distinct regional characteristics. Along the Okhotsk Sea coast (observation sites 605 and 609), correlations are moderate compared with the Pacific coast. Significantly high correlations $(>0.7)$ are seen at the observation sites along the coast of northern Tohoku. Meanwhile, the correlations are not significant at observation sites 47418 and 613 located southeast of Hokkaido and at observation site 218 in Sendai Bay where the coastlines are open to the south. The lack of significant correlations indicates that the waves observed at these sites depend only weakly on the waves propagating westward under the persistent easterly winds. Thus, we can confirm that the relation shown in Fig. 4a holds true mostly along the Pacific and Okhotsk Sea coasts of northern Japan.

The significant high correlations along the coast of northern Tohoku indicate the impact of the strong northeasterly winds occurring in the lee of Cape Erimo on wave development toward the coast (Shimada \& Kawamura 2007). Fan-shaped winds with a spatial extent up to $150 \mathrm{~km}$ and speeds typically $>10 \mathrm{~m} \mathrm{~s}^{-1}$ frequently develop in the lee of the cape owing to the topographic effects on the low-level cool airflow induced by the developed Okhotsk high. Wind waves quickly respond to the strong local winds blowing toward the Pacific coast of northern Tohoku. Fig. 4b shows the significant correlation between the northeasterly wind component at Cape Erimo and the Tsugaru Strait index. Thus, the occurrence of the strong winds in the lee of Cape Erimo enhances the response of the coastal waves along the Pacific coast of northern Tohoku to the easterly winds induced by the Okhotsk high.

The relations between SWH along the Pacific and Okhotsk Sea coasts of northern Japan and the 2 Yamase indices are supported by composite analysis of wave reanalysis data (Fig. 5). The composites in Fig. 5 are made following the method of Shimada et al. (2014) for the atmospheric field; Fig. 5 shows mean composites of SWH and of mean wave direction where the normalized indices exceed 1 standard deviation. The anomalies with respect to the climatological mean in June-August are also shown. Corresponding to the enhanced easterly winds represented by the 2 indices (Fig. 9c,d in Shimada et al. 2014), SWH is enhanced to the east of northern Japan. For the SWH field represented by the Tsugaru Strait index (Fig. 5a), the SWH anomaly is $>0.3 \mathrm{~m}$ near the Pacific coast of northern Japan. For the SWH field represented by the Soya Strait index (Fig. 5b), positive anomalies of SWH in the south of the Okhotsk Sea are apparent. These results are consistent with the coastal wave variability shown in Fig. 2. To the east of northern Japan, the mean wave directions in these composites shift more to the west than in the climatology (Fig. 1), reflecting the dominant easterly winds. The other common features in the wave fields around Japan are discussed in Section 4. 

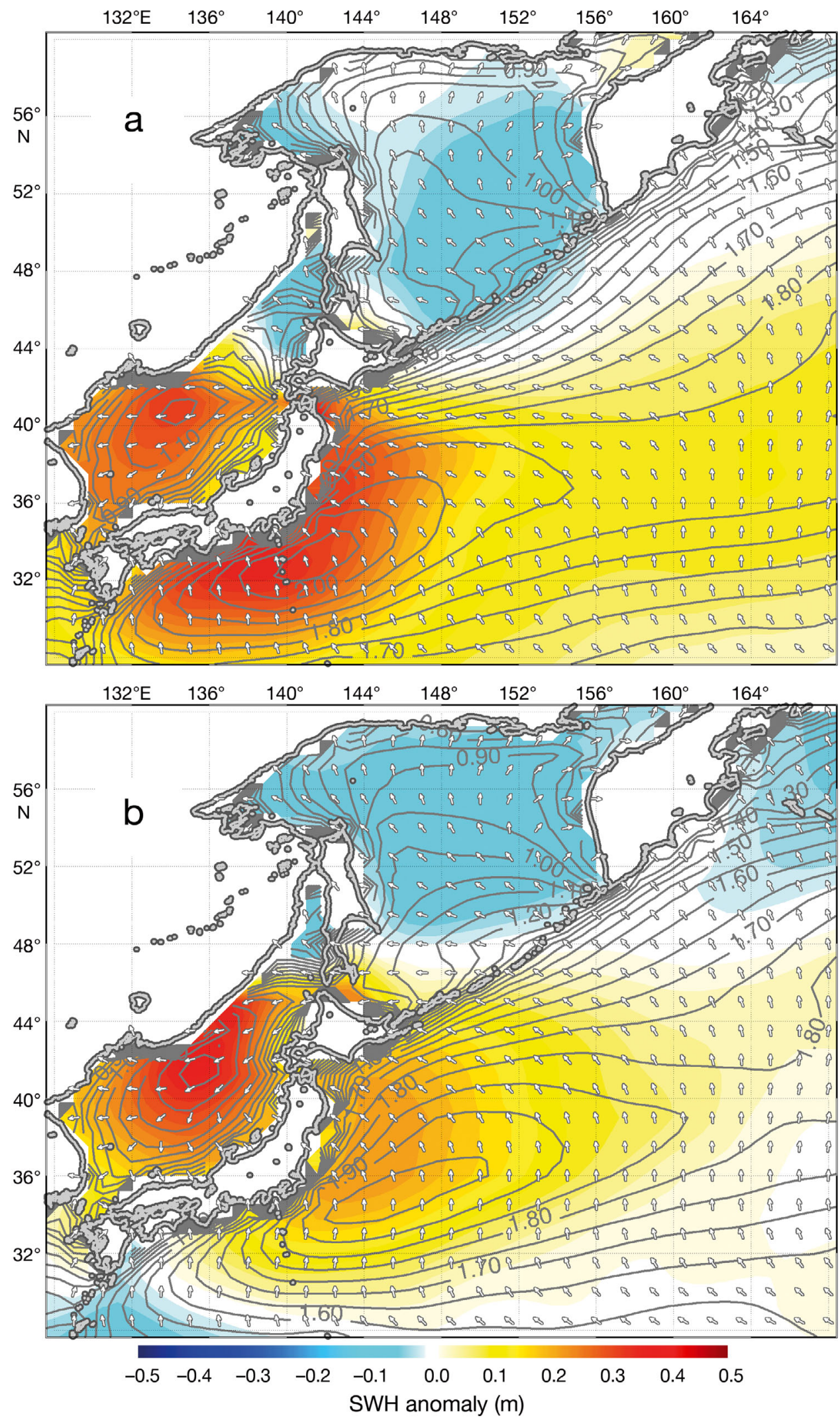

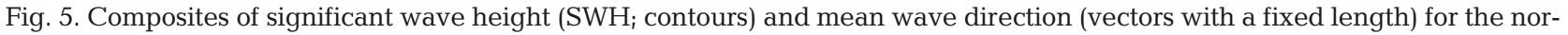
malized (a) Tsugaru Strait index and (b) Soya Strait index exceeding 1 standard deviation. Contour interval is $0.05 \mathrm{~m}$. Color shading indicates SWH anomalies with respect to the climatological mean in June-August for 32 yr (1979-2010) in Fig. 1 with p = 0.95 


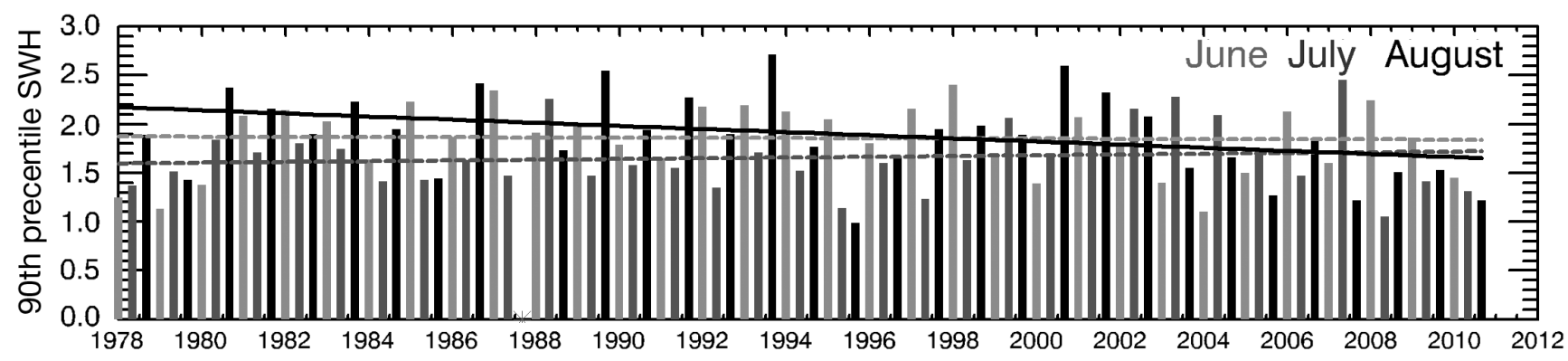

Fig. 6. Monthly 90th percentile significant wave height ( $\mathrm{SWH}_{;}$bars) in June-August at observation site 47590 and monthly linear trends (3 lines). The solid line denotes a statistically significant trend and the dashed lines denote insignificant trends

\section{DISCUSSION}

It is worthwhile examining the summertime wave fields under the developed Okhotsk high in regions around Japan other than the east coast of northern Japan (Fig. 5). Reduction in the SWH in the Okhotsk Sea is due to the reduced southerly winds and weak winds around the center of the Okhotsk high. The $\mathrm{SWH}$ in the Japan Sea shows a noticeable increase of $>0.2 \mathrm{~m}$ compared with the climatological mean. This is consistent with the organized strong winds over the Japan Sea (Fig. 9c,d in Shimada et al. 2014). An increase in SWH is seen along the southern coast of Japan, and the areas of SWH $>2.0 \mathrm{~m}$ correspond to the northeastward low-pressure extension representing the Baiu frontal zone (e.g. Ninomiya \& Murakami 1987), seen in the SLP composites (Fig. 7c,d in Shimada et al. 2014). Thus, high SWH along the southern coast of Japan reflects the frequent passage of low-pressure systems in the Baiu frontal zone and the persistent southerly winds blowing to this zone. As the Tsugaru Strait index represents the Baiu frontal zone located more to the south of Japan than the Soya Strait index (Fig. 7c,d in Shimada et al. 2014), the increases in SWH along the southern coast of Japan are greater in the composite by the Tsugaru Strait index (Fig. 5a) than by the Soya Strait index (Fig. 5b). Wave directions generally shift more northward than the wind directions in the western North Pacific and the Okhotsk Sea (Fig. 9c,d in Shimada et al. 2014), which suggests the overall impact of swells from the south.

In addition to the monthly variability of $\mathrm{SWH}$, it is examined whether there is a statistically significant trend in wave height. Trends in wave height are increasingly gaining attention in association with climate change (e.g. Young et al. 2011, Sasaki 2012). Observation sites with data for over 20 yr are selected and the trends are quantified as linear functions over time series of monthly 90th-percentile
SWH by the least squares method. Two methods are used to test the significance of the trend (Sneyers 1990): the trend-to-noise ratio test and the nonparametric Mann-Kendall trend test. Both tests provide consistent results for trend significance. Fig. 6 is an example of monthly 90th percentile $\mathrm{SWH}$, and estimated trends for each month in June-August at observation site 47590. There are no significant trends for June and July at any of the selected sites. However, for August, a significant decreasing trend is seen at observation sites 47590 (Fig. 6), 205, 214, and 206, which are located in the south of northern Japan (Table 1). While these trends hold true for monthly mean SWH, the decreasing trend in August becomes more statistically significant for the higher percentile $\mathrm{SWH}$. These results suggest that the summertime decreasing trends in SWH and wave energy, shown by Sasaki (2012), are due to the decreasing trends in SWH in August. Meanwhile, no significant trends are obtained for the Tsugaru Strait index in any of the 3 mo. Thus, the decreasing trend in SWH in August is not associated with the long-term trend of the easterly winds induced by the developed Okhotsk high.

The SWH variability and the decreasing trend in SWH in August may be influenced by the frequency and tracks of tropical cyclones. Along the southern coast of Japan, the coastal wave climate in summer is heavily influenced by tropical cyclones (Sasaki et al. 2005, Sasaki \& Hibiya 2007). Fewer tropical cyclones approached Japan after 2003. Moreover, most of the tropical cyclones after 2003 passed over Japan or the Japan Sea, not east of northern Japan. Indeed, for observation site 47590 , the years 2003-2010, with the exception of 2006, are within the lowest $10 \mathrm{yr}$ for 90th percentile SWH in August in the $33 \mathrm{yr}$ of observations. These facts suggest the possibility that the trends in wave height are caused by long-term variation of high waves induced by the tropical cyclones passing east of northern Japan. 


\section{CONCLUSIONS}

By analyzing in situ measurements of waves, this study has shown that in summer, the variability in SWH along almost the entire Pacific and Okhotsk Sea coasts of northern Japan is influenced by the Okhotsk high. When the Okhotsk high develops and easterly winds persistently blow toward northern Japan, high waves are observed along the Pacific and Okhotsk Sea coasts of northern Japan. The impact of the easterly winds on coastal waves is especially enhanced along the coast of northern Tohoku because of the fan-shaped strong local winds formed in the lee of Cape Erimo. Wave fields derived from the reanalysis data support these conclusions and show increased SWH near the coast of and to the east of northern Japan. In addition, SWH increases in the Japan Sea owing to the organized strong winds and increases along the southern coast of Japan owing to the Baiu frontal zone, whereas SWH decreases in the Okhotsk Sea owing to the reduced southerly winds. Significant decreasing trends in SWH are found in the south of northern Japan in August.

Acknowledgements. The author thanks the editor and three anonymous reviewers for their constructive suggestions. This study was supported by a Grant-in-Aid for Scientific Research and by the Research Program on Climate Change Adaptation of the Japanese Ministry of Education, Culture, Sports, Science and Technology.

\section{LITERATURE CITED}

Arakawa H, Suda K (1953) Analysis of winds and swell over the sea to the east of Japan during the typhoon of September 26, 1935. Mon Weather Rev 81:31-37

Caires S, Swail VR, Wang XL (2006) Projection and analysis of extreme wave climate. J Clim 19:5581-5605

> Charles E, Idier D, Thiébot J, Le Cozannet G, Pedreros R, Ardhuin F, Planton S (2012) Present wave climate in the Bay of Biscay: spatiotemporal variability and trends from 1958 to 2001. J Clim 25:2020-2039

> Dee DP, Uppala SM, Simmons AJ, Berrisford P and others (2011) The ERA-Interim reanalysis: configuration and performance of the data assimilation system. QJR Meteorol Soc 137:553-559

Fan Y, Lin SJ, Held IM, Yu Z, Tolman HL (2012) Global ocean surface wave simulation using a coupled atmosphere-wave model. J Clim 25:6233-6252

Hemer MA, Fan Y, Mori N, Semedo A, Wang XL (2013) Projected change in wave climate from a multi-model ensemble. Nat Clim Change 3:471-476

Lionello P, Sanna A (2005) Mediterranean wave climate variability and its links with NAO and Indian Monsoon. Clim Dyn 25:611-623

Editorial responsibility: Eduardo Zorita, Geesthacht, Germany
Mori N, Yasuda T, Mase H, Tom T, Oku Y (2010) Projection of extreme wave climate change under global warming. Hydro Res Lett 4:15-19

Ninomiya K, Mizuno H (1985) Anomalously cold spell in summer over northeastern Japan caused by northeasterly wind from polar maritime air-mass. Part 1. EOF analysis of temperature variation in relation to the largescale situation causing the cold summer. J Meteorol Soc Jpn 63:845-857

Ninomiya K, Murakami T (1987) The early summer rainy season (Baiu) over Japan. In: Chang CP, Krishnamurti TN (eds) Monsoon meteorology. Oxford University Press, Oxford, p 93-121

Sasaki W (2012) Changes in wave energy resources around Japan. Geophys Res Lett 39:L23702, doi:10.1029/2012GL 053845

Sasaki W, Hibiya T (2007) Interannual variability and predictability of summertime significant wave heights in the western North Pacific. J Oceanogr 63:203-213

Sasaki W, Iwasaki SI, Matsuura T, Iizuka S, Watabe I (2005) Changes in wave climate off Hiratsuka, Japan, as affected by storm activity over the western North Pacific. J Geophys Res 110:C09008, doi: 10.1029/2004JC002730

Shimada T, Kawamura H (2004) Wind jets and wind waves off the Pacific coast of northern Japan under winter monsoon captured by combined use of scatterometer, synthetic aperture radar, and altimeter. J Geophys Res 109: C12027, doi:10.1029/2004JC002450

Shimada T, Kawamura H (2007) Case study of wind jet transition and localized responses of wind wave along the Pacific coast of northern Japan by synergetic use of satellite and in situ observations. J Oceanogr 63:953-966

> Shimada T, Sawada M, Iwasaki T (2014) Indices of cool summer climate in northern Japan: Yamase indices. J Meteorol Soc Jpn 92:17-35

> Shimura T, Mori N, Mase H (2013) Ocean waves and teleconnection patterns in the Northern Hemisphere. J Clim 26:8654-8670

Sneyers R (1990) On the statistical analysis of series of observations. Tech Note No. 143, World Meteorological Organization, Geneva

Stopa JE, Cheung KF, Tolman HL, Chawla A (2013) Patterns and cycles in the Climate Forecast System Reanalysis wind and wave data. Ocean Model 70:207-220

> Tachibana Y, Iwamoto T, Ogi M, Watanabe Y (2004) Abnormal meridional temperature gradient and its relation to the Okhotsk high. J Meteorol Soc Jpn 82:1399-1415

> Wang XL, Swail VR (2001) Changes of extreme wave heights in Northern Hemisphere oceans and related atmospheric circulation regimes. J Clim 14:2204-2221

- Wang XL, Swail VR (2006) Climate change signal and uncertainty in projections of ocean wave heights. Clim Dyn 26:109-126

WASA group (1998) Changing waves and storms in the Northeast Atlantic? Bull Am Meteorol Soc 79:741-760

> Woolf DK, Challenor PG, Cotton PD (2002) Variability and predictability of the North Atlantic wave climate. J Geophys Res 107:3145, doi:10.1029/2001JC001124

Young IR (1999) Seasonal variability of the global ocean wind and wave climate. Int J Climatol 19:931-950

> Young IR, Zieger S, Babanin AV (2011) Global trends in wind speed and wave height. Science 332:451-455

Submitted: March 25, 2014; Accepted: August 3, 2014

Proofs received from author(s): October 26, 2014 